EVIDENCE BASED PUBLIC HEALTH POLICY AND PRACTICE

\title{
Predicted health impacts of urban air quality management
}

\section{J Mindell, M Joffe}

J Epidemiol Community Health 2004;58:103-113

See end of article for authors' affiliations

....................

Correspondence to: Dr J Mindell, Department of Epidemiology and Public Health, Imperial College London, St Mary's Campus, Norfolk Place, London W2 IPG, UK; j.mindell@imperial.ac.uk

Accepted for publication 27 October 2003

\begin{abstract}
Study objective: The 1995 UK Environment Act required local authorities to review air quality and, where UK National Air Quality Strategy objectives (except ozone) are likely to be exceeded in 2005, to declare local air quality management areas and prepare action plans. This study modelled the impacts on health of reductions from current levels of $\mathrm{PM}_{10}$ to these objectives.

Design: The framework for conducting quantified health impact assessment assessed causality, then, if appropriate, examined the shape and magnitude of the exposure-response relations. The study modelled declines in pollution to achieve the objectives, then modelled the numbers of deaths and admissions affected if air pollution declined from existing levels to meet the objectives, using routine data.

Setting: Westminster, central London.

Main results: Attaining the $2004 \mathrm{PM}_{10} 24$ hour objective in Westminster results in 1-21 lives no longer shortened in one year (annual deaths 1363). Reducing exceedences from 35 to seven almost doubles the estimates. The 2009 objective for the annual mean requires a substantial reduction in $\mathrm{PM}_{10}$, which would delay 8-20 deaths. About 20 respiratory and 14-20 circulatory admissions would be affected and around $5 \%$ of emergency hospital attendances for asthma by attaining the lower annual mean target. The effects of long term exposure to particulates may be an order of magnitude higher: models predict about 24 deaths are delayed by reaching the 2004 annual target $\left(40 \mu \mathrm{g} / \mathrm{m}^{3}\right.$ [gravimetric] $)$ and a hundred deaths by reducing annual mean $\mathrm{PM}_{10}$ to $20 \mu \mathrm{g} / \mathrm{m}^{3}$ [gravimetric].

Conclusions: Modelling can be used to estimate the potential health impacts of air quality management programmes.
\end{abstract}

$\mathrm{T}$ he United Kingdom 1995 Environment Act required the development of a National Air Quality Strategy for the UK. ${ }^{12}$ This set standards for eight outdoor air pollutants: sulphur dioxide, lead, carbon monoxide, ozone, nitrogen dioxide, benzene, 1,3-butadiene, and particulates, measured as the mass of $\mathrm{PM}_{10}$ particles, collected through a size selective inlet that collects $50 \%$ of particles of $10 \mu \mathrm{m}$ aerodynamic diameter, $>95 \%$ of $5 \mu \mathrm{m}$ particles and $<5 \%$ of $20 \mu \mathrm{m}$ diameter particles (hence $\mathrm{PM}_{10}$ : particulate mass with less than $10 \mu \mathrm{m}$ diameter). The act required each local authority to review air quality and, where target levels other than for ozone are likely to be exceeded in the year 2005, to declare a local Air Quality Management Area, and prepare an action plan.

Many of the highest levels in the UK of $\mathrm{PM}_{10}$ and nitrogen dioxide are found in central London. ${ }^{3}$ Westminster City Council, a central London borough with an estimated resident population of 216244 in 2000 and an average annual mortality of 1363, has designated the whole borough an Air Quality Management Area as it will continue to exceed the UK National Air Quality Strategy targets for $\mathrm{PM}_{10}$ and nitrogen dioxide, although it will meet the objectives for the other pollutants.

We modelled the acute impacts on health of meeting the UK National Air Quality Strategy objectives, which require a reduction from the current levels of these two pollutants to the targets shown in table 1. We applied the method to Westminster, using a model that is generalisable to any area with raised levels of pollution.

\section{METHOD}

We developed a four stage framework for quantifying the potential health impacts of air pollution reduction (fig 1).

\section{Literature review}

We conducted a systematic literature review of epidemiological papers examining the effects of particulates and/or nitrogen dioxide, following the principles given by the World Health Organisation guidance ${ }^{5}$ both for searching for relevant publications and for appraising the studies. A comprehensive bibliographic search was conducted, using Medline (19662002); BIDS-Embase (1980-2002); Biological Abstracts (1991-1998) and the Health Management Information Consortium (HMIC) CD-ROM, which included "grey" literature. Other sources of information were expert reports commissioned by the government and publications cited in other references. Search terms are detailed by Mindell. ${ }^{6}$

The search produced 410 studies of particulate matter, published by December 2001, of which 38 were of poor quality or irrelevant. An additional 52 studies were published in 2002. Assessment of the effects of air pollution is based on studies with good data collection, appropriate analysis, and in circumstances that can be extrapolated to pollution in London. ${ }^{6}$ Altogether 220 epidemiological studies were found on the effects of nitrogen dioxide, of which nine were of poor quality or irrelevant. An additional 27 studies were published in 2002 .

\section{Is there a causal association?}

The published studies and reports were examined firstly for evidence of an association. Where one of the pollutants was associated with a specific effect on health, consideration was given to whether or not this was likely to be attributable to confounding. Where unconfounded associations were found, consideration was then given to the possibility that these were likely to be causal relations, by assessing the evidence using Bradford Hill's viewpoints. ${ }^{7}$

Abbreviations: APHEA, short term effects of air pollution on health: European approach; NMMAPS, national mortality and morbidity air pollution study; COPD, chronic obstructive pulmonary disease; TEOM, tapered element oscillating microbalance; ACS, American Cancer Society study; GAM, generalised additive models 


\begin{tabular}{|c|c|c|c|c|}
\hline $\begin{array}{l}\text { UK National Air Quality Strategy targets } \\
\text { used in this study }\end{array}$ & UK target & Baseline levels in Westminster & & \\
\hline 1: Annual mean $\mathrm{PM}_{10} 30.8 \mu \mathrm{g} / \mathrm{m}^{3}$ [TEOM] & UK target for 31.12 .2004 & Annual mean $\mathrm{PM}_{10}$ & & \\
\hline $\begin{array}{l}\left(40 \mu \mathrm{g} / \mathrm{m}^{3} \text { [gravimetric] }\right) \\
\text { 2: Annual mean PM } 1015.4 \mu \mathrm{gg} / \mathrm{m}^{3} \text { [TEOM] } \\
\left(20 \mu \mathrm{g} / \mathrm{m}^{3} \text { [gravimetric] }\right)\end{array}$ & UK target for 31.12 .2009 & $36 \mu \mathrm{g} / \mathrm{m}^{3}$ in 1996 & $38 \mu \mathrm{g} / \mathrm{m}^{3}$ in 1997 & $31 \mu \mathrm{g} / \mathrm{m}^{3}$ in 1998 \\
\hline $\begin{array}{l}\text { 3: } 24 \mathrm{hour} \text { mean PM } \mathrm{PMO}_{10} 38.5 \mu \mathrm{g} / \mathrm{m}^{3} \text { [TEOM] } \\
\left(50 \mu \mathrm{g} / \mathrm{m}^{3} \text { [gravimetric] }, \leqslant 35 \mathrm{exceedences}\right. \\
\text { 4: } 24 \mathrm{hour} \text { mean PM } \mathrm{M}_{10} 38.5 \mu \mathrm{g} / \mathrm{m}^{3} \text { [TEOM] } \\
\left(50 \mu \mathrm{g} / \mathrm{m}^{3} \text { [gravimetric] }\right) \leqslant 7 \text { exceedences }\end{array}$ & $\begin{array}{l}\text { revised UK target for } \\
31.12 .2004 \\
\text { proposed UK target for } \\
31.12 .2009\end{array}$ & $\begin{array}{l}24 \mathrm{hr} \text { mean } \mathrm{PM}_{10} \text { of } 38.5 \mu \mathrm{g} / \mathrm{m}^{3} \text { [TEOM] } \\
\left(50 \mu \mathrm{g} / \mathrm{m}^{3} \text { [gravimetric]), exceeded: }\right. \\
114 \text { times in } 1996\end{array}$ & 130 times in 1997 & 67 times in 1998 \\
\hline $\begin{array}{l}\text { I: Annual mean nitrogen dioxide } \\
40 \mu \mathrm{g} / \mathrm{m}^{3}(21 \mathrm{ppb}) \text {, } \\
\text { II: Hourly mean nitrogen dioxide } 286 \mathrm{\mu g} / \mathrm{m}^{3}\end{array}$ & target for 31.12 .2005 & $\begin{array}{l}\text { Annual mean nitrogen dioxide } \\
43 \mathrm{ppb} \text { in } 1996 \\
\text { No of hours }>150 \text { pob }\end{array}$ & $42 \mathrm{ppb}$ in 1997 & $43 \mathrm{ppb}$ in 1998 \\
\hline $\begin{array}{l}\text { II: Hourly mean nitrogen dioxide } 286 \mu \mathrm{g} / \mathrm{m}^{3} \\
\text { (150 ppb) }\end{array}$ & $\begin{array}{l}\text { original UK National Air } \\
\text { Quality Strategy target for } \\
31.12 .2005\end{array}$ & $\begin{array}{l}\text { No of hours }>150 \mathrm{ppb} \\
5 \text { in } 1996\end{array}$ & 0 in 1997 & 0 in 1998 \\
\hline $\begin{array}{l}\text { III: Hourly mean nitrogen dioxide } 200 \mu \mathrm{g} / \mathrm{m}^{3} \\
(105 \mathrm{ppb}), \leqslant 18 \text { exceedences }\end{array}$ & $\begin{array}{l}\text { target for } 31.12 .2005 \text { in } \\
\text { revised strategy }\end{array}$ & $\begin{array}{l}\text { No of hours }>105 \mathrm{ppb} \\
32 \text { in } 1996\end{array}$ & 30 in 1997 & 2 in 1998 \\
\hline
\end{tabular}

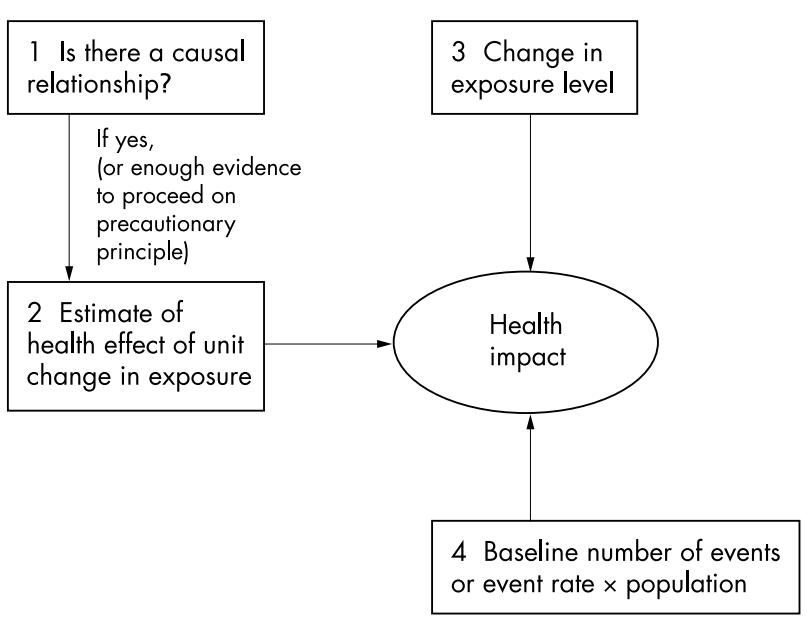

Figure 1 Four stage framework for quantifying the potential health impacts.

The systematic review concluded that in the case of acute exposure to ambient particles, the evidence for a causal relation was sufficiently strong for the range of health outcomes given in table 2 . Far fewer studies have examined the long term effects of air pollution; particulates have been associated with increased mortality in three American $^{8-10}$ and one Dutch ${ }^{11}$ cohort studies, even after re-analysis adjusting for a wide range of socio-demographic and other potential confounders. ${ }^{12}$ The effect is likely to be causal.

For nitrogen dioxide, the evidence is much less clear. Although recent studies have generally shown associations between the ambient level of the gas and a number of cardiorespiratory outcomes, the evidence for causality is much weaker. The consensus is that the relation is probably not causal but that nitrogen dioxide is almost certainly acting as a proxy measure for another pollutant from traffic, probably fine particulates. We have therefore not presented results of health effects for reducing nitrogen dioxide.

\section{Estimate of the health effect of a unit change in exposure}

There are three elements to this: determining the shape of the relation, whether there is a threshold, and the magnitude of the effect.

Several studies have examined different models and have demonstrated a log-linear relation between average particulate concentration and relative risk. ${ }^{13-19}{ }^{20-23}$ Most studies have assumed that the relation between relative risk and pollution is linear, that is relative risk or percentage change in outcome of a given increment in pollutant does not change across the range of pollutant levels examined. For brevity, the term linear is used here in this sense. Although some studies found the relation to be curvilinear, ${ }^{24} 25$ these are at concentrations well in excess of those now found in the UK; the WHO advised that in the range $20-200 \mu \mathrm{g} / \mathrm{m}^{3} \mathrm{PM}_{10}$, the relation is linear. ${ }^{26}$

No threshold (or at least none above about $20 \mu \mathrm{g} / \mathrm{m}^{3}$ ) has been found for acute effects on mortality in Madrid, ${ }^{27}$ Milan, ${ }^{28}$ Seattle, ${ }^{29}$ Birmingham (Alabama), ${ }^{20}$ London, $^{30}$ or Atlanta, ${ }^{31}$ or for deaths from COPD or heart failure in Milan, ${ }^{28}$ for admissions for pneumonia or chronic obstructive airways diseases in older adults in Birmingham (Alabama), ${ }^{32}$ nor for IHD admissions in Detroit. ${ }^{18}$ Recent studies confirmed that a

\begin{tabular}{|c|c|c|c|}
\hline \multicolumn{2}{|l|}{ Mortality } & \multicolumn{2}{|l|}{ Morbidity } \\
\hline $\begin{array}{l}\text { Strong } \\
\text { evidence }\end{array}$ & Moderate evidence & $\begin{array}{l}\text { Strong } \\
\text { evidence }\end{array}$ & Moderate evidence \\
\hline $\begin{array}{l}\text { All non- } \\
\text { traumatic } \\
\text { deaths-acute } \\
\text { effects }^{44}\end{array}$ & $\begin{array}{l}\text { All respiratory disease. }{ }^{37} \\
\text { Chronic obstructive } \\
\text { pulmonary disease plus } \\
\text { asthma in people aged } \\
\geqslant 655^{37} \mathrm{All} \text { non-traumatic } \\
\text { deaths - effects of long } \\
\text { term exposure. }{ }^{1251}\end{array}$ & & $\begin{array}{l}\text { Emergency hospital admissions for all circulatory }{ }^{36} \text { and } \\
\text { all respiratory diseases } \\
\text { at all ages. Emergency hospital admissions in people } \\
\text { aged } \geqslant 65 \text { for chronic obstructive pulmonary disease } \\
\text { plus asthma } a^{36} \text { and for pneumonia }{ }^{36} \text { Asthma admissions } \\
\text { in children and younger adults. } \\
\text { emergency attendances for asthma in children and } \\
\text { younger adults }\end{array}$ \\
\hline
\end{tabular}


linear model performed best for total and cardiorespiratory mortality ${ }^{23}{ }^{33}$; any threshold is $\approx 15 \mu \mathrm{g} / \mathrm{m}^{23}$ or $<5 \mu \mathrm{g} / \mathrm{m}^{3}$ $\mathrm{PM}_{10}{ }^{33}$ We therefore assumed there is no threshold for the effects of particulates, in line with World Health Organisation conclusions. ${ }^{26}{ }^{34}$

\section{Exposure-response coefficient}

We present models for those outcomes where the evidence for a causal relation with particulates is at least moderately strong in our view or where reports for government or international bodies have so concluded.

For each acute outcome-pollutant pair for which there was strong or moderate evidence of a causal relation, we chose the effect estimates from time-series studies that used untransformed pollution levels that were most relevant to current pollution in central London:

- results from the most recent time-series study in London for that pollutant and health outcome ${ }^{30}{ }^{35-38}$;

- results of pooled analyses from APHEA studies (short term effects of air pollution on health: European approach) in Western Europe, also a primary study, as the sources and levels of pollution were similar to London and the power of the pooled study was substantially greater than for most of the single studies available. Recently, results from the APHEA-2 studies, covering a population of more than 43 million people in 29 European cities have been published..$^{38-41}$

- estimates based on recent meta-analyses not subject to publication bias (the combined NMMAPS (national mortality and morbidity air pollution study)-APHEA meta-analysis $)^{42}$ or conducted for the World Health Organisation, ${ }^{26}{ }^{43}$ including those that were the basis of the 1998 COMEAP report on the burden of disease in the UK attributable to pollution. ${ }^{44}$

Meta-analyses were not used as the sole effect estimate, nor did we conduct our own, because:

- many studies of ostensibly the same end points use different case definitions;

- many studies use different age groups;

- studies used different metrics of pollutants;

- each meta-analysis should contain only results from unipollutant models or with the same co-pollutant; and

- studies using single and cumulative lags should be analysed separately.

Although some authors have converted other measures of particulate matter into " $\mathrm{PM}_{10}$-equivalents" for their reviews or meta-analyses, we did not do this because of their well documented variability. ${ }^{24}$ 44-50

Where they exist, effect estimates that allow for the effects of other relevant pollutants would have been used, to permit addition of effects without double-counting. However, these were seldom available. Most studies have also found greater effects of pollution using cumulative rather than single day lag. Ideally, effect estimates that incorporate both copollutants and cumulative exposure would have been used but in practice, these are seldom available. Often, neither are available.

Although the three sources of effect estimates were chosen a priori, in practice, they were not available for all outcomes. Table 3 gives the range of effects estimates considered for acute effects of exposure to particulates, using the criteria above.

We also estimated the effect on all cause mortality of chronic $\mathrm{PM}_{10}$ exposure, although the paucity of good quality cohort studies and the different metrics used limited the effect estimates that could be selected. Most studies used fine particulates $\left(\mathrm{PM}_{2.5}\right)$ rather than $\mathrm{PM}_{10}$ as their metric: where this was the case, we applied this effect estimate to the $\mathrm{PM}_{10}$ levels although this would be an overestimate because some of the $\mathrm{PM}_{10}$ is $\mathrm{PM}_{2.5-10}$.

We used:

- the effect observed in those with more than high school education in the reanalysis of the six cities study, to eliminate as far as possible many of the potential socioeconomic confounders ${ }^{12}$ : $0.3 \%$ per $1 \mu \mathrm{g} / \mathrm{m}^{3} \mathrm{PM}_{2.5}$;

- the all cause effect estimate from the 16 year follow up of the American Cancer Society cohort ${ }^{15}: 0.4 \%$ per $1 \mu \mathrm{g} / \mathrm{m}^{3}$ $\mathrm{PM}_{2.5}$;

- the variance weighted average of the 1995 ACS follow up and the six cities study calculated by Künzli et al in their three country study for the World Health Organisation ${ }^{52}$ : $0.43 \%$ per $1 \mu \mathrm{g} / \mathrm{m}^{3} \mathrm{PM}_{10}$; and

- the effect estimate deemed "most likely" by COMEAP in their 2001 statement ${ }^{53}: 0.1 \%$ per $1 \mu \mathrm{g} / \mathrm{m}^{3} \mathrm{PM}_{2.5}$.

- We also estimated the effects on life expectancy of long term exposure to reduced particulate levels. The best estimate is that lifelong exposure to $10 \mu \mathrm{g} / \mathrm{m}^{3} \mathrm{PM}_{10}$ shortens average life expectancy by 18.6 weeks per person across the whole population ( 13 days per $\left.1 \mu \mathrm{g} / \mathrm{m}^{3} \mathrm{PM}_{10}\right) .^{54}$ This assumes that the population is exposed to that pollution from birth until death or 105 years of age and that there is no delay before effects are seen. We applied the effects to the population now alive, with the full range of ages present, and made the assumption that the effects are spread evenly over the years of exposure. We assumed a life expectancy of 75 years.

\section{Calculating the effect of a reduction in pollution}

Effect estimates were calculated for a rise of $1 \mu \mathrm{g} \mathrm{m}^{-3} 24 \mathrm{~h}$ $\mathrm{PM}_{10}$, assuming a linear relation with no threshold*. The $95 \%$ confidence intervals have been calculated where it was possible to do so†.

We based our calculations for the effects of short term changes in pollution on the following formula:

$$
\Delta \mathrm{E}=\beta \times \Delta \mathrm{C} \times \mathrm{E}
$$

where

$\Delta \mathrm{E}=$ change in number of outcome events, $\beta=$ exposureresponse coefficient, $\Delta \mathrm{C}=$ change in ambient concentration, and $\mathrm{E}=$ baseline number of outcome events.

(This assumes a log-linear exposure-response function with no threshold, and is arithmetically equivalent to the formula given by Ostro and Chestnut..$^{55}$ )

\section{Change in ambient concentration}

Air pollution measurements

We used data from three years (1996-1998) for the baseline for air pollutant levels because meteorological conditions can vary considerably from year to year. In particular, these change the peak levels and the number of days on which higher levels occur, even if emissions remain constant.

Continuous measurements of $\mathrm{PM}_{10}$ have been made in Westminster by a roadside tapered element oscillating

*Relative risk (RR) for a $1 \mu \mathrm{g} / \mathrm{m}^{3}$ increase in pollutant $=\mathrm{e}^{\beta}$ where $\beta$ is the regression coefficient for a $1 \mu \mathrm{g} / \mathrm{m}^{3}$ change in pollutant. Percentage increase in outcome for a $1 \mu \mathrm{g} / \mathrm{m}^{3}$ increase in pollutant $=100$ (RR-1). $95 \%$ confidence intervals (Cl) for RR for a $1 \mu \mathrm{g} / \mathrm{m}^{3}$ increase in pollutant $=e^{(\beta \pm 1.96 S E)}$, where $\beta$ is the regression coefficient for a $1 \mu \mathrm{g} /$ $\mathrm{m}^{3}$ change in pollutant and $\mathrm{SE}$ is the standard error of $\beta$. 


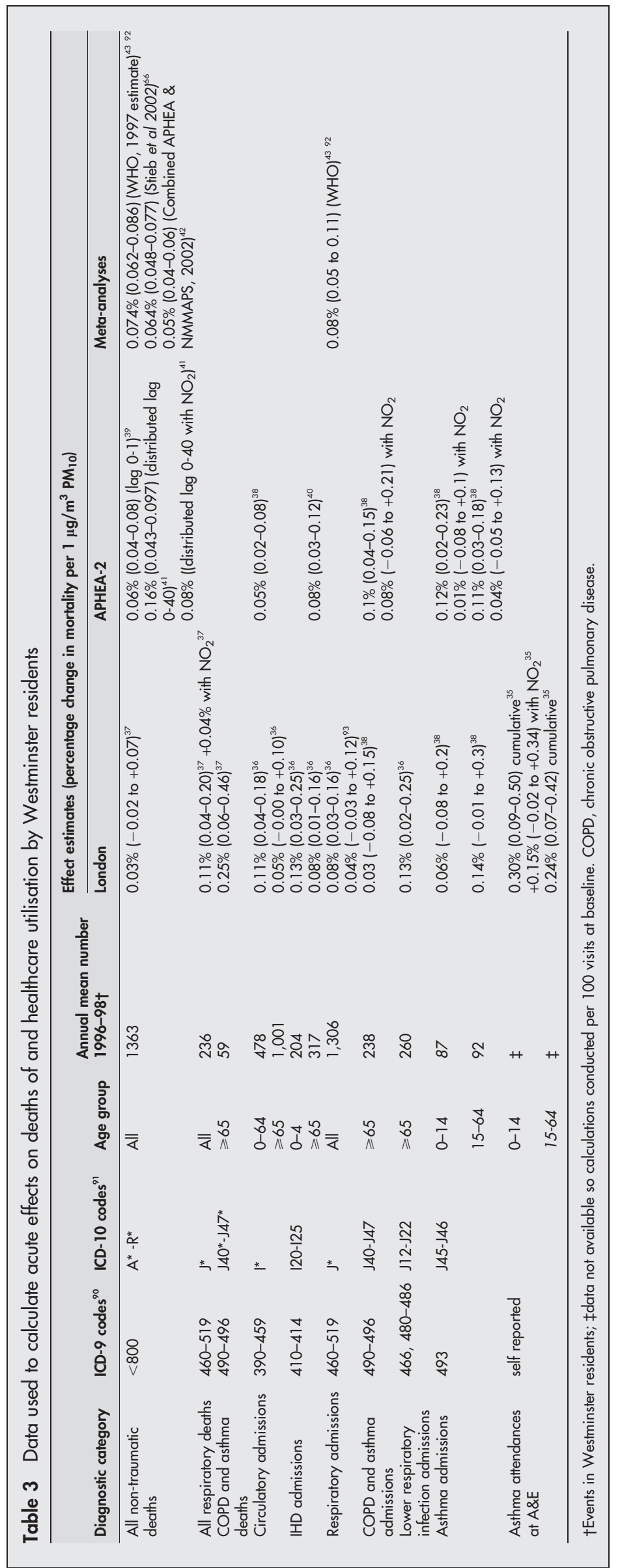



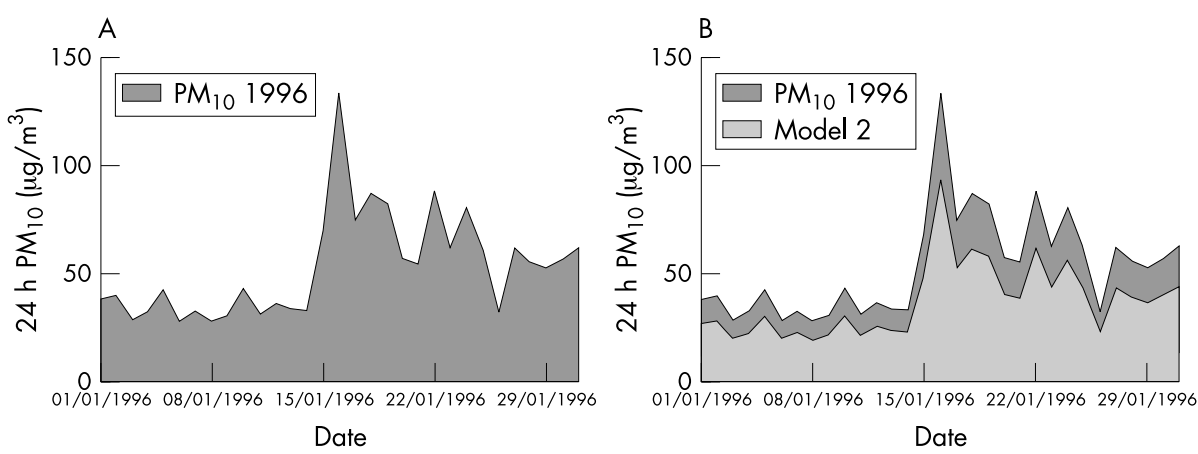

Figure 2 Three theoretical models for patterns of air pollution reduction. (A) $24 \mathrm{~h} \mathrm{PM} 10$ levels in Westminster, January 1996. (B) $24 \mathrm{~h} \mathrm{PM} 10$ levels in Westminster, January 1996 and effect of model B. (C) $24 \mathrm{~h} \mathrm{PM}_{10}$ levels in Westminster, January 1996 and effect of model A. (D) $24 \mathrm{~h} \mathrm{PM} 10$ levels in Westminster, January 1996 and effect of model $\mathrm{C}$.

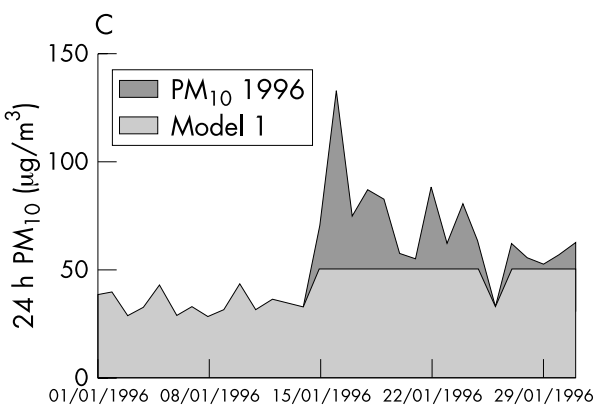

Date

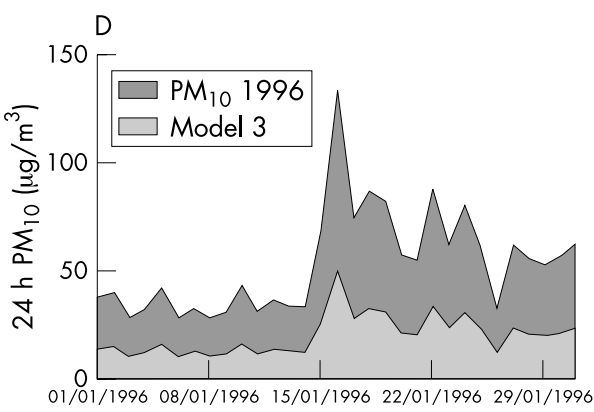

Date

Table 4 Effects on premature deaths delayed by reducing PM $_{10}$ in Westminster from 1996-1998 roadside levels to UK standards

\begin{tabular}{|c|c|c|c|c|c|c|c|c|}
\hline \multirow{3}{*}{$\begin{array}{l}\text { Cause of } \\
\text { death }\end{array}$} & \multirow[b]{3}{*}{ Age } & \multirow[b]{3}{*}{ Source } & \multicolumn{2}{|c|}{$\begin{array}{l}\text { Reductions to achieve } \mathrm{PM}_{10} \\
\text { annual mean objective }\end{array}$} & \multirow{3}{*}{$\begin{array}{l}\text { Reductions to achieve } \\
24 \mathrm{~h} \text { PM10 target for } \\
31.12 .2004 \\
50 \mu \mathrm{g} / \mathrm{m}^{3} \text { [gravimetric] } \\
\text { with } 35 \text { permitted } \\
\text { exceedences } \\
\text { Model } 3 \mathrm{~b}\end{array}$} & \multirow{3}{*}{$\begin{array}{l}\text { Reductions to achieve } \\
24 \mathrm{~h} \mathrm{PM10} \text { target for } \\
31.12 .2009 \\
50 \mu \mathrm{g} / \mathrm{m}^{3} \text { [gravimetric] with } \\
7 \text { permitted exceedences } \\
\text { Model } 4 \mathrm{~b}\end{array}$} & \multicolumn{2}{|c|}{$\begin{array}{l}\text { Effect of reducing pollution } \\
\text { to } 0 \mu \mathrm{g} / \mathrm{m}^{3}\end{array}$} \\
\hline & & & \multirow{2}{*}{$\begin{array}{l}40 \mu \mathrm{g} / \mathrm{m}^{3} \\
\text { [gravimetric] } \\
\text { Model 1d }\end{array}$} & \multirow{2}{*}{$\begin{array}{l}20 \mu \mathrm{g} / \\
\mathrm{m}^{3} \text { [gravimetric] } \\
\text { Model } 2 \mathrm{~d}\end{array}$} & & & \multirow{2}{*}{$\begin{array}{l}\text { No of } \\
\text { deaths } \\
\text { delayed } \\
\text { pa }\end{array}$} & \multirow{2}{*}{$\begin{array}{l}\text { Deaths delayed } \\
\text { as } \% \text { of total } \\
\text { deaths in a } \\
\text { year }\end{array}$} \\
\hline & & & & & & & & \\
\hline \multirow{9}{*}{$\begin{array}{l}\text { Total non- } \\
\text { traumatic }\end{array}$} & \multirow[t]{9}{*}{ All } & London & 1.7 & 8.0 & 1.9 & 3.1 & 14.3 & $1.0 \%$ \\
\hline & & APHEA*-2 (lag 0-1) & 3.3 & 16 & 3.9 & 6.3 & 29 & $2.5 \%$ \\
\hline & & $\begin{array}{l}\text { APHEA-2 (distributed } \\
\text { lag } 0-40 \text { ) }\end{array}$ & 8.9 & 43 & 10 & 17 & 76 & $56 \%$ \\
\hline & & $\begin{array}{l}\text { APHEA-2 (distributed } \\
\operatorname{lag} 0-40 \text {, with } \mathrm{NO}_{2} \text { ) }\end{array}$ & 4.3 & 20 & 5.0 & 8.0 & 37 & $2.7 \%$ \\
\hline & & $\begin{array}{l}\text { NMMAPS† } \\
\text { (original) }\end{array}$ & 2.3 & 11 & 2.7 & 4.3 & 20 & $1.4 \%$ \\
\hline & & NMMAPS (revised) & 1.2 & 5.6 & 1.4 & 2.2 & 10 & $0.7 \%$ \\
\hline & & COMEAP & 4.1 & 19.6 & 4.8 & 7.7 & 35.2 & $2.6 \%$ \\
\hline & & Stieb et al & 3.6 & 17 & 4.1 & 6.7 & 30 & $2.2 \%$ \\
\hline & & $\begin{array}{l}\text { NMMAPS (original) } \\
\text { pooled with APHEA-2 }\end{array}$ & 2.8 & 13 & 3.2 & 5.2 & 24 & $1.7 \%$ \\
\hline \multirow{6}{*}{$\begin{array}{l}\text { Respiratory } \\
\text { COPD and } \\
\text { asthma } \\
\text { Total non- } \\
\text { traumatic } \\
\text { (chronic } \\
\text { exosure) }\end{array}$} & All & London & 0.4 & 1.8 & 0.4 & 0.7 & 3.3 & $1.4 \%$ \\
\hline & $\geqslant 65$ & London & 0.6 & 2.9 & 0.7 & 1.1 & 5.2 & $8.8 \%$ \\
\hline & All & $16 y r$ ACS* & 22 & 106 & & & & \\
\hline & & $\begin{array}{l}\text { Six cities study: HEI } \\
\text { reanalysis* }\end{array}$ & 17 & 80 & & & & \\
\hline & & Kunzli $(95 \% \mathrm{Cl})$ & 24 (14 to 34$)$ & 114 (69 to 162 & & & & \\
\hline & & $\begin{array}{l}\text { COMEAP "most } \\
\text { likely" effect estimate* }\end{array}$ & 6 & 27 & & & & \\
\hline
\end{tabular}


Table 5 Effects on admissions and consultations prevented or delayed by reducing $\mathrm{PM}_{10}$ in Westminster from 1996-1998 roadside levels to UK standards

\begin{tabular}{|c|c|c|c|c|c|c|c|c|}
\hline \multirow{3}{*}{$\begin{array}{l}\text { Emergency } \\
\text { hospital } \\
\text { admissions }\end{array}$} & \multirow[b]{3}{*}{ Age } & \multirow[b]{3}{*}{ Source } & \multicolumn{2}{|c|}{$\begin{array}{l}\text { Reductions to achieve } \\
\mathrm{PM}_{10} \text { annual mean } \\
\text { objective }\end{array}$} & \multirow{2}{*}{$\begin{array}{l}\text { Reductions to } \\
\text { achieve } 24 \mathrm{~h} \text { - } \\
\text { PM10 target for } \\
31.12 .2004 \\
50 \mu \mathrm{g} / \mathrm{m}^{3} \\
\text { [gravimetric] } \\
\text { with } 35 \text { permitted } \\
\text { exceedences }\end{array}$} & \multirow{2}{*}{$\begin{array}{l}\text { Reductions to achieve } \\
24 \mathrm{~h}-\mathrm{PM} 10 \text { target for } \\
31.12 .2009 \\
50 \mu \mathrm{g} / \mathrm{m}^{3} \text { [gravimetric] } \\
\text { with } 7 \text { permitted } \\
\text { exceedences }\end{array}$} & \multicolumn{2}{|c|}{$\begin{array}{l}\text { Effect of reducing pollution to } \\
0 \mu \mathrm{g} / \mathrm{m}^{3}\end{array}$} \\
\hline & & & $\begin{array}{l}40 \mu \mathrm{g} / \mathrm{m}^{3} \\
\text { [gravimetric] }\end{array}$ & $\begin{array}{l}20 \mu \mathrm{g} / \mathrm{m}^{3} \\
\text { [gravimetric] }\end{array}$ & & & \multirow{2}{*}{$\begin{array}{l}\text { No of events } \\
\text { prevented } \\
\text { or delayed pa }\end{array}$} & \multirow{2}{*}{$\begin{array}{l}\text { Events delayed } \\
\text { as } \% \text { of } \\
\text { total events } \\
\text { in a year }\end{array}$} \\
\hline & & & Model Id & Model 2d & Model 3b & Model $4 b$ & & \\
\hline \multirow[t]{2}{*}{ Respiratory } & \multirow{2}{*}{ All } & London & 4.3 & 20 & 5.0 & 8.0 & 36 & 2.8 \\
\hline & & COMEAP & 4.3 & 20 & 5.0 & 8.0 & 36 & 2.8 \\
\hline \multirow[t]{6}{*}{ Asthma } & \multirow[t]{3}{*}{$0-14$} & London & 0.2 & 1.0 & 0.2 & 0.4 & 0.8 & 2.1 \\
\hline & & APHEA-2 & 0.4 & 2.0 & 0.5 & 0.8 & 3.6 & 4.2 \\
\hline & & $\begin{array}{l}\left.\text { APHEA-2(+NO }{ }_{2}\right) \\
\left(+\mathrm{NO} 2 \mathrm{NNO} 2 \mathrm{NO}_{2}\right)\end{array}$ & 0.0 & 0.2 & 0.0 & 0.1 & 0.3 & 0.3 \\
\hline & \multirow[t]{3}{*}{$15-64$} & London & 0.5 & 2.5 & 0.6 & 1.0 & 4.5 & 4.9 \\
\hline & & APHEA-2 & 0.4 & 2.0 & 0.5 & 0.8 & 3.5 & 3.8 \\
\hline & & APHEA-2 $\left(+\mathrm{NO}_{2}\right)$ & 0.2 & 0.7 & 0.2 & 0.3 & 1.3 & 1.4 \\
\hline \multirow{3}{*}{ COPD + asthma } & \multirow[t]{3}{*}{$\geqslant 65$} & London & 0.3 & 1.4 & 0.3 & 0.5 & 2.5 & 1.0 \\
\hline & & APHEA-2 & 1.0 & 4.6 & 1.1 & 0.8 & 8.3 & 3.5 \\
\hline & & APHEA-2 $\left(+\mathrm{NO}_{2}\right)$ & 0.8 & 3.7 & 0.9 & 1.5 & 6.6 & 2.8 \\
\hline LRTI & $\geqslant 65$ & London & 1.4 & 6.6 & 1.6 & 2.6 & 12 & 4.6 \\
\hline \multirow[t]{3}{*}{ Circulatory } & $0-64$ & London & 2.1 & 10 & 2.5 & 4.0 & 18 & 3.8 \\
\hline & $\geqslant 65$ & & 2.0 & 9.7 & 2.4 & 3.8 & 7.4 & 1.7 \\
\hline & All & APHEA-2 & 3.0 & 14 & 3.5 & 5.6 & 26 & 1.7 \\
\hline \multirow[t]{3}{*}{ IHD } & $0-64$ & London & 1.1 & 5.2 & 1.3 & 2.0 & 9.2 & 4.4 \\
\hline & $\geqslant 65$ & London & 1.0 & 4.9 & 1.2 & 1.8 & 8.8 & 2.8 \\
\hline & & APHEA-2 & 1.0 & 4.9 & 1.2 & 1.8 & 8.8 & 2.8 \\
\hline \multicolumn{9}{|l|}{ A\&E attendance* } \\
\hline \multirow[t]{3}{*}{ Asthma } & $0-14$ & London $\left(+\mathrm{NO}_{2}\right)$ & 0.6 & 2.9 & 0.7 & 1.2 & N/A & 5.2 \\
\hline & & London (cumulative) & 1.2 & 5.8 & 1.4 & 2.3 & $\mathrm{~N} / \mathrm{A}$ & 10.5 \\
\hline & $15-64$ & & 1.0 & 4.7 & 1.1 & 1.8 & N/A & 8.4 \\
\hline
\end{tabular}

*Figures for accident and emergency department attendances are given as a percentage of the baseline attendance rate. COPD, chronic obstructive pulmonary disease; LRTI, lower respiratory tract infection; IHD, ischaemic heart disease.

microbalance (TEOM) monitor on Marylebone Road since 1995. The particulate objectives are set for gravimetric measurements. TEOM monitors under-record by about $30 \%$ in comparison with this, ${ }^{2}$ so $38.5 \mu \mathrm{g} / \mathrm{m}^{3}{ }_{\text {[ТЕOM] }}$ approximates to $50 \mu \mathrm{g} / \mathrm{m}^{3}$ [gravimetric]. The local authority supplied us with hourly $\mathrm{PM}_{10}$ levels for the three years, from which we calculated 24 hour mean $\mathrm{PM}_{10}$ for each day. Background $\mathrm{PM}_{10}$ TEOM measurements in Bloomsbury, near Westminster in central London, were also obtained from the London Borough of Camden.

Modelling the declines in air pollution

Irrespective of the policy instruments proposed or the feasibility of achieving the targets, there are three general ways in which the hourly or daily pollution profile could change (fig 2).

\section{Key points}

- Ambient particulates cause adverse health effects in urban areas even at current UK levels.

- Reducing pollution in Westminster to national targets proposed for 2009 will delay 8-20 deaths as a result of acute exposure and about 100 per year as a result of long term exposure.

- The achievable health gain from reducing pollution is far less than the total health damage attributable to pollution.
- In Model A, all peaks above the standard (excluding permitted exceedences) have been eliminated. Levels on other days remain unchanged.

- Model B assumes that the mean percentage decline in pollutant on the peak days, based on model A, also occurs on the remaining days.

- Model C uses the percentage reduction required to eliminate the highest peak (excluding permitted exceedences) to reduce each day's pollution.

Models A and C provide lower and upper bounds, respectively; B models an intermediate condition. (Model A is the pattern that might be obtained by closing a city to motor vehicles when high pollutant levels are forecast; model C represents what might be seen in the long term, for example because of traffic reduction plus reduced transboundary pollution.) The target is not necessarily achieved by model $\mathrm{B}$, as applying the average decline over all the exceedence days results in some of those days remaining above the standard but this is probably a more realistic estimate of the magnitude, if not the distribution, of the decline in pollutant. The simplest change is the reduction required to reach the target for the annual mean (model D in tables 2-4).

We also estimated the health effects of reducing $\mathrm{PM}_{10}$ levels to zero to compare with the Department of Health's report on the burden of disease attributable to particulates. ${ }^{44}$

\section{Baseline number of outcome events}

We used health outcome data for the same three calendar years (1996-1998) for the baseline; this reduces errors attributable to random fluctuations of small numbers of events. Mortality data came from the Office for National Statistics and emergency hospital admissions from Hospital 
Episode Statistics. No data were available on accident and emergency or general practice consultations locally, so results were calculated as a percentage of baseline age and disease specific consultations.

\section{Creating the spreadsheets}

\section{Modelling the declines in air pollution}

For each applicable combination of air quality target and pollution reduction model for each of the three baseline years, spreadsheets calculate the magnitude of change in ambient air pollution. Technical problems with the measuring devices can cause missing data for hours or days. Ignoring these underestimates the magnitude of the decline in pollution. We therefore imputed mean values to the missing data.

\section{Health outcomes}

For each air pollution reduction model, estimates of the number of lives no longer shortened or of emergency hospital admissions or consultations not occurring or not brought forward in a year were calculated automatically by multiplying the daily event number by the chosen effect estimate and the decline in pollutant summed over a year. In view of the uncertainties attached to both the effect estimates and the decline in pollution, we used a sensitivity analysis approach with three estimates for each where possible.

\section{RESULTS}

\section{Short term effects}

Attaining the $200424 \mathrm{~h} \mathrm{PM} 10$ objective at the Westminster roadside monitoring site, using the TEOM equivalent of $38.5 \mu \mathrm{g} / \mathrm{m}^{3}$, results in one to four fewer deaths brought forward, based on the London studies, three to 21 based on the pooled APHEA-2 results from Western Europe, one to nine, based on Stieb et al's 2002 meta-analysis, and one to 10 based on the World Health Organisation meta-analysis used by the Department of Health ${ }^{44}$ (table 4). Reducing the permitted number of exceedences from 35 to the seven permitted in 2009 almost doubles the estimates. More respiratory and cardiovascular emergency admissions than deaths are delayed, because of the higher numbers of baseline events but the order of magnitude is similar (table 5). For example, about five respiratory and three to five cardiovascular admissions would be prevented or delayed by achieving the 2004 daily objective with an intermediate decline in pollution (model B). The fewer permitted exceedences for 2009 increases these to eight respiratory and six to eight cardiovascular admissions.

The annual mean $\mathrm{PM}_{10}$ levels changed less than the number and extent of the exceedences of the 24 hour standard in the three baseline years. Achieving the annual mean objective for 2004 would delay between two and four deaths, using most effect estimates (table 4). More admissions are delayed or prevented by achieving these objectives (table 5). The 2009 objective for the annual mean requires a substantial reduction in $\mathrm{PM}_{10}$, which would delay eight to 20 deaths, using the same effect estimates. About 20 respiratory and 14-20 circulatory admissions would be affected as well as around 5\% of A\&E attendances for asthma by attaining the lower annual mean target.

To check the models, we estimated the effects of reducing $\mathrm{PM}_{10}$ pollution in Westminster to zero, to calculate the burden of disease attributable to particulates (tables 4 and 5). Deaths attributable to $\mathrm{PM}_{10}$ ranged from $1.0 \%$ of the total, using the London exposure-effect coefficient, to $5.6 \%$, using the distributed lag 0-40d APHEA-2 effect estimate $(2.7 \%$ using the effect estimate that included nitrogen dioxide in the analysis). More than one in eleven deaths in Westminster from obstructive lung diseases in the 65-74 age group were

\section{Policy implications}

- Local authorities' legal duty for air quality management was introduced to obtain health benefits; achievable health gain from reducing pollution is much less than the total health damage attributable to pollution.

- With no threshold of effect for particulates, more stringent air quality targets yield greater health benefits.

- Most air pollution in the UK comes from motor vehicles. Benefits to health and wellbeing of reducing trafficreductions in injuries, greenhouse gas emissions, noise, and community severance from reduced car use accompanied by large positive health effects from increasing walking and cycling, are likely to be substantially greater than benefits from applying technical fixes to current travel patterns.

attributable to $\mathrm{PM}_{10}$. For emergency hospital admissions, the main groups affected by particulates are also adults with obstructive airways diseases: $\mathrm{PM}_{10}$ caused almost 5\% of emergency admissions in adults under 65 with asthma and up to $3.5 \%$ of admissions in those aged $\geqslant 65$ with chronic obstructive pulmonary disease or asthma.

\section{Long term effects}

The effects on mortality of long term exposure to particulates may be an order of magnitude higher (table 5). Results using the 16 year follow up from the American Cancer Study are similar to those using Künzli and colleagues' estimate for the long term effect of $\mathrm{PM}_{10}$ on mortality, and slightly higher than using Krewski's reanalysis of the six cities: about 20 deaths are delayed by reaching the 2004 annual target $\left(40 \mu \mathrm{g} / \mathrm{m}^{3}\right.$ [gravimetric] $)$ and a hundred deaths by reducing annual mean $\mathrm{PM}_{10}$ to $20 \mu \mathrm{g} / \mathrm{m}^{3}$ [gravimetric]. Calculations using the COMEAP "most likely" effect estimate are one quarter the magnitude, being closer to the acute effects of $\mathrm{PM}_{10}$, particularly when a distributed lag is used for those acute effects.

The mean reduction in annual $\mathrm{PM}_{10}$ for the roadside monitor is $4 \mathrm{ug} / \mathrm{m}^{3}$ for the 2004 target and $19.5 \mu \mathrm{g} / \mathrm{m}^{3}$ for the 2009 target. Ten year exposure to these lower levels would increase life expectancy by 7.3 and 34 days respectively, on average.ł

\section{Choice of monitoring site}

Particulate levels measured at the roadside in Westminster were higher than those at the background site in nearby Bloomsbury. The latter already met the 2004 annual mean target and almost met the 200424 hour target. To meet the 2009 targets, the decline required in pollution was one third to one half that required to achieve the same levels at the roadside in Westminster. The estimated health effects were lower by the same proportion (data not shown). Ten years exposure to the 2009 target rather than 1996-98 average levels at the Bloomsbury background site would increase average life expectancy by 19 days.§

$\$ 4.2 \mu \mathrm{g} / \mathrm{m}^{3} \times 13 \mathrm{~d}$ per $1 \mu \mathrm{g} / \mathrm{m}^{3} \quad \mathrm{PM}_{10} \times 10 / 75=7.3 \mathrm{~d} ; 19.5 \mu \mathrm{g} /$ $\mathrm{m}^{3} \times 13 \mathrm{~d}$ per $1 \mu \mathrm{g} / \mathrm{m}^{3} \mathrm{PM}_{10} \times 10 / 75=34 \mathrm{~d}$

$\$ 11 \mu \mathrm{g} / \mathrm{m}^{3} \times 13 \mathrm{~d}$ per $1 \mu \mathrm{g} / \mathrm{m}^{3} \mathrm{PM}_{10} \times 10 / 75=19 \mathrm{~d}$ 


\section{DISCUSSION}

\section{Attributable risk and achievable health gain}

The comparison of our zero pollution findings with the Department of Health report $\mathrm{t}^{44}$ demonstrates two main points. Our results using the same effect estimate suggests that 2.6\% of deaths in Westminster were associated with baseline pollution levels. This compares well with the estimate for the Department of Health that $1.9 \%$ of urban deaths are attributable to $\mathrm{PM}_{10}$ pollution, ${ }^{44}$ as $\mathrm{PM}_{10}$ levels are higher in central London than almost anywhere else in the UK. Similarly, $\mathrm{PM}_{10}$ in 1996-1998 accounted for $2.8 \%$ of all respiratory admissions, a little more than the report's national estimate of $2.0 \%$.

Secondly, the number of deaths or hospital admissions affected by the proposed reduction in air pollution is small compared with the total that is attributable to particulate air pollution. Attribution of a quantified burden of disease to a particular risk factor is quite different from quantifying the achievable health gain for a specified policy or target. This corresponds to a focus on the change in exposure rather than its level. ${ }^{56}$

We have assumed that the observed effects of pollution are reversible by reduced exposure; this has been shown in a number of locations. ${ }^{34}$

\section{Choice of health outcome measures}

Most HIA guidance advocates a holistic approach to health, including positive measures of good health. ${ }^{57}$ However, we were limited to using routine data, which are available only for disease measures, although they are not ideal outcome measures because few people are affected. As prevalence of mild disease is more common, more residents are likely to be affected by pollution exacerbating milder symptoms. While there is evidence that pollution affects lower respiratory symptoms and changes in lung function, we were not able to include these outcomes because of the lack of suitable routine data or of sufficient good quality information about general practitioner consultations.

The specific causes of mortality and morbidity were those identified by our systematic literature review as having at least moderate evidence for a causal relation with particulates. Few published meta-analyses have considered this first step, ${ }^{6}$ the 1998 COMEAP report being a notable exception. ${ }^{44}$ Omitting this crucial first step would have led us to report effects on mortality and hospital admissions of declines in levels of nitrogen dioxide. Our decision not to do so is in line with the most recent authoritative review. ${ }^{34}$

\section{Estimation of exposure-response functions}

The choice of exposure-response coefficients depends on what is available. This is subject to change as new studies are published or methods are re-evaluated. The spreadsheets are designed so that these coefficients can be replaced easily.

International collaboration has resulted in studies using identical methods in a number of cities. In addition to examining local effects, pooled analyses are planned at the start; all study sites provide relevant information, regardless of their results. These calculations provide a much more robust estimate of the true effect.

Meta-analyses also combine results from a number of studies to give a more precise estimate. Expert reports have generally put most emphasis on meta-analyses but unlike pooled analyses, they are subject to publication bias so are more likely than pooled analyses to overestimate effects. Publication bias is the most probable explanation for the higher rate found in earlier American studies than the larger, more recent ones in the USA and in Europe.

The largest study is the American national morbidity, mortality, and air pollution study (NMMAPS), based on deaths in the 90 largest cities in the USA. ${ }^{58} 59$ Like many time series studies, it was analysed using generalised additive models (GAM). Investigators have found recently that when estimated regression coefficients are small and the default settings on the gam function of S-Plus software do not assure convergence of its iterative estimation procedure, the results overestimate the regression coefficients by $36 \%-42 \% .{ }^{60}$ The effect estimate is more sensitive to the choice of method for adjustment for temporal effects than to the convergence criteria used. ${ }^{61}$ The greater the degree of concurvity (the nonparametric analogue of multicolinearity) the greater the overestimation of the regression coefficient. ${ }^{60}$ Concurvity also underestimates variance in the model and therefore the standard errors of linear predictors produced by the gam function are biased downwards, inflating type I errors. ${ }^{62}$ Stieb et al have shown a $23 \%-41 \%$ reduction in effect estimates from meta-analyses of primary $\mathrm{PM}_{10}$ studies not analysed with GAM compared with meta-analyses of studies using GAM analyses. ${ }^{63}$

Reanalysis of the NMMAPS data using generalised linear models (GLM) and natural cubic splines instead of GAM and smoothing splines to adjust for confounders halves the pooled estimate for non-traumatic mortality from $+0.41 \%$ to $+0.21 \%$ per $10 \mu \mathrm{g} / \mathrm{m}^{3} \mathrm{PM}_{10}$; GAM used with stricter convergence criteria gives an estimate of $0.27 \%{ }^{60}{ }^{64}$ The highest relative risk, for cardiorespiratory deaths, changed much less. ${ }^{61}{ }^{65}$ Ramsay et al repeated Stieb et al's meta-analysis of 31 studies of daily $\mathrm{PM}_{10}$ and mortality. ${ }^{66}$ They found a slightly lower effect estimate $\left(0.18 \%\right.$ instead of $0.20 \%$ per $10 \mu \mathrm{g} / \mathrm{m}^{3}$ $\mathrm{PM}_{10}$ ) but the variance in the original meta-analysis was underestimated by $23 \%{ }^{62}$ These effect estimates are all within the same order of magnitude as those shown in table 3 (listed there per $1 \mu \mathrm{g} / \mathrm{m}^{3} \mathrm{PM}_{10}$ ).

The effect of any reduction in the magnitude of the effect estimate once problems with GAM and with concurvity have been dealt with is to reduce the results by the same proportion. For example, the predicted number of deaths no longer delayed by reaching the annual mean target for 2009 therefore falls from 11 to 5.6 when the original is replaced with the revised estimate from NMMAPS (table 4). Corrected GAM analyses do not, however, affect the results from the pooled APHEA studies. ${ }^{67}$ This is because multisite time series are analysed using hierarchical models that estimate uncertainty in the pooled estimate using total variance. $^{64}$ The WHO has reported that the unpublished meta-analysis from St George's, London, of 26 studies that have not used GAM in analysis resulted in an effect estimate of $0.4 \%$ per $10 \mu \mathrm{g} / \mathrm{m}^{3} \quad \mathrm{PM}_{10}$, similar to the uncorrected NMMAPS result. ${ }^{34}$ The effect estimate using a 40 day distributed lag suggests that effect estimates from analyses using a few days' lag are probably underestimates. $^{41}$

Most studies of long term effects of particulates have used fine particulates not $\mathrm{PM}_{10}$ as the metric; the WHO have recently recommended that a standard for $\mathrm{PM}_{2.5}$ be established because of the increasing evidence that this fraction contains the principal harmful particles. ${ }^{34}$ Our models used $\mathrm{PM}_{10}$ not only because that is the particulate measure used for the objectives in the current and proposed UK National Air Quality Strategy but also because $\mathrm{PM}_{10}$ is now measured routinely but $\mathrm{PM}_{2.5}$ is not. The results for the long term effects of $\mathrm{PM}_{10}$ using $\mathrm{PM}_{2.5}$ is an overestimate because some of the $\mathrm{PM}_{10}$ is $\mathrm{PM}_{2.5-10}$; these coarser particles may also affect health ${ }^{63}$ but the evidence for that is less consistent. ${ }^{34}$

Another contentious issue is whether effect estimates from uni-pollutant or multi-pollutant models should be used. It is advisable to use results from multi-pollutant models when examining the effect of more than one pollutant. As our 
initial step indicated that the apparent effects of nitrogen dioxide are probably a proxy for effects of other traffic related pollutants and pollutants other than particulates and nitrogen dioxide are not of concern in central London, it is debatable whether it is appropriate to make such adjustments. In practice, few studies have reported such effect estimates. We have given results from the APHEA-2 distributed lag study $y^{41}$ for analyses including and excluding nitrogen dioxide.

\section{Sensitivity analyses}

Confidence intervals allow for random error but not for systematic error. The three estimates for the decline in pollution for each target (models A, B, and C), excluding annual mean, and the use of a number of exposure-response coefficients constitute built in sensitivity analyses. Analyses using pollution reductions based on each baseline year separately can be used for further sensitivity analyses (data available on request). Fortuitously, meteorological conditions resulted in particularly frequent exceedences of the $\mathrm{PM}_{10}$ daily objective in 1996 and 1997 and unusually few in 1998. We have also calculated the effects based on air pollution measurements from two different sites.

There has been much media attention given to the annual fluctuations in peak levels and number of exceedences of these two pollutants. These are reflected in differing falls in pollution required to reach the hourly or 24 hour objectives using the different years as baseline. Use of mean values does not distinguish between longer exposures to lower levels and shorter exposures to higher levels of pollution. Abbey and Burchette used a number of metrics, namely the frequency of exceedences and the excess concentration for four predetermined cut off values of TSP in the well designed California Seventh Day Adventists cohort study. Excess concentration $>200 \mu \mathrm{g} / \mathrm{m}^{3}$ was the metric that correlated best with incidence of bronchitis, asthma or COPD and with change in severity of asthma. ${ }^{68}$

\section{Validity of using fixed monitor measurements of air pollution}

Ambient pollution is only a proxy for personal exposure and dose, so studies relating levels of air pollution at a fixed site monitor to health outcomes probably underestimate the effect of pollution. ${ }^{69}$ However, it is important to use the same definition of exposure as that used in the studies from which the exposure-response functions have been derived.$^{70}$ There is no reason to believe that the relation between residents' exposure and the fixed site monitor is substantially different in central London from the studies we used. Those most affected by pollution are those who are already ill, who are unlikely to be highly mobile, so their spatial relation to the fixed site monitor is likely to be more consistent than for healthy people.

Comparing $\mathrm{PM}_{10}$ levels at the two sites, hourly values, which vary more than 24 hour mean levels, were higher at the roadside monitor in Marylebone Road than the background site at Bloomsbury in 1995 but for many months, the levels varied almost in parallel. ${ }^{71}$ Since then, peak levels have fallen. In 1996 and 1998, $24 \mathrm{~h}-\mathrm{PM}_{10}$ was $>50 \mu \mathrm{g} / \mathrm{m}_{\text {[TEOM] }}^{3}$ at the Bloomsbury background site more often than at the Marylebone roadside site. ${ }^{72}$ Crossroads sites, such as the Marylebone Road roadside monitor, are midway between a severe canyon site and a background site, picking up fresh emissions from the nearest street in certain wind directions and benefiting from the ventilation of the canyon down the side roads in other wind directions. ${ }^{73}$ They are therefore not as different from background measurements as might be imagined.
Roadside levels generally represent less well most people's exposure to pollution but $\mathrm{PM}_{10}$ and $\mathrm{PM}_{2.5}$ levels outside individuals' homes tracked fixed site $\mathrm{PM}_{10}$ levels. ${ }^{74}$ Westminster City Council's Air Quality Management Plan aims to bring roadside levels down to meet the standards. Background levels in Westminster would therefore fall to levels below the targets. As there is no observed threshold for effects on health and the exposure-response relation is approximately linear in this range, the effect is determined by the magnitude of the reduction not the absolute level reached. Therefore these calculations are likely to be reasonable estimates of the effects on deaths and admissions brought forward.

\section{Magnitude of results}

It is important to note that the figures we have calculated for the acute effects of pollutants are unlikely to represent a decline in annual mortality as most if not all of the affected people would have died within the year. The results shown are the number of people whose death in that year would have been brought forward had the pollution not declined.

Ostro and Chestnut argue that a proportion of these deaths would have been so premature that a change in annual mortality does occur ${ }^{75}$ but this is disputed..$^{76} 77$ It had been assumed that most of the people affected by air pollution are probably dying a few days, weeks, or months before they would have died without exposure to the air pollution but Zeger et al showed that the theory that deaths due to acute pollution exposure are due only to "harvesting" of the very frail is inconsistent with their analysis of the data, ${ }^{78}$ which showed that Poisson regression time-series analyses have underestimated the exposure-effect coefficient. ${ }^{78}{ }^{79}$ For pneumonia, ${ }^{80}$ myocardial infarction, ${ }^{80}$ and all cause mortality, ${ }^{78} 80$ exposure to ambient air pollution is probably shortening life to a greater extent than was previously thought. This adds weight to our use of the larger, distributed lag effect estimates from APHEA-2. ${ }^{41}$ Additionally, the long term effects of chronic exposure to lower levels of pollution are generally held to be considerably larger than the acute effects. ${ }^{78}$ However, even over a lifetime's exposure, the effects of these reductions on life expectancy is small compared with the average 12 years of life lost by smokers killed by tobacco. ${ }^{81}$

\section{Impacts on inequalities in health}

Those at greatest risk from air pollution are those with preexisting cardiorespiratory disease. ${ }^{34283}$ Both cardiovascular and respiratory disease are more common in less affluent and less educated groups in the UK. In Canada, the highest prevalence of several risk factors for respiratory disease was in the area with the highest ambient pollution levels. ${ }^{84}$ In London there is a linear relation between levels of $\mathrm{PM}_{10}$ and deprivation; with the greatest predicted falls in the areas of greatest deprivation. ${ }^{85}$ Reducing air pollution will therefore decrease inequalities both because exposure will be reduced most in deprived areas and because those who will benefit most are those with worse health, the very young and older people.

The spreadsheets we have developed are designed to model the most severe impacts on residents' health of reductions from current levels of $\mathrm{PM}_{10}$ in a local authority area to the UK National Air Quality Strategy targets. They have been piloted by three local authorities and a health authority in west London and have been used by 35 other local authorities in the UK. The same method could be applied to other pollutants.

Models A, B, and C represent patterns of decline in pollutant levels but do not correspond directly to policy options to achieve such declines. The next step will be to combine the approach used in this study with one based on 
actual sources and the ways in which emissions can be reduced.

This paper has considered only the direct health gains of air pollution reduction, such as would be obtained by reducing emissions using technical fixes without changing behaviour. The benefits to health and wellbeing of changing travel patterns, with reductions in injuries, greenhouse gas emissions, noise and community severance from reduced car $u^{3 e^{86} 87}$ accompanied by the large positive health effects from increasing walking ${ }^{88}$ and cycling, ${ }^{89}$ have the potential to increase much further the health benefits of air quality management. ${ }^{56}$

\section{ACKNOWLEDGEMENTS}

We thank Guy Denington, Hugh Donohoe, Amanda Gudgeon, and Kyri Eleftheriou-vaus, Royal Borough of Kensington and Chelsea; Chris Cawley, Steve Neville, and Joy Thompson, City of Westminster; and Mark Amos, Dorothy Gregson, John H James, and Ian Stinson of Kensington and Chelsea and Westminster Health Authority for their help with this work. The spreadsheets are available to local authorities and NHS organisations from the authors.

\section{Authors' affiliations}

J Mindell, M Joffe, Department of Epidemiology and Public Health, Imperial College School of Science, Technology and Medicine, London, UK

\section{REFERENCES}

1 Department of the Environment, Scottish Office, Welsh Office. The United Kingdom national air quality strategy. London: The Stationery Office, 1997.

2 Department of the Environment Transport and the Regions. The air quality strategy for England, Scotland, Wales and Northern Ireland. London: TSO, 1999.

3 Barratt B, Beevers S, Buckingham C et al. The AIM project and air quality in London 1996. The fourth report of the London air quality network. Tunbridge Wells: South East Institute of Public Health, 1997.

4 Smith S. Nitrogen dioxide "Adopt-a-Tube" scheme, Royal Borough of Kensington and Chelsea. Croydon: Stanger Science and Environment, 1997.

5 World Health Organisation Working Group. Evaluation and use of epidemiological evidence for environmental health risk assessment: WHO Guideline document. Environ Health Perspect 2000;108:997-1002. http:// ehpnet1 .niehs.nih.gov/docs/2000/108p997-1002krzyzanowski/ abstract.html (accessed 19 Aug 2003)

6 Mindell JS. Quantification of the health impacts of air pollution reduction in Kensington \& Chelsea and Westminster. London: Imperial College of Science, Technology and Medicine, University of London, October, 2002

7 Hill AB. The environment and disease: association or causation? Proc Roy Soc Med 1965; 58:295-300

8 Dockery DW, Pope CAl, $X_{u} X$, et al. An association between air pollution and mortality in six U.S. cities. N Engl J Med 1993;329:1753-9.

9 Abbey DE, Nishino N, McDonnell WF, et al. Long-term inhalable particles and other air pollutants related to mortality in nonsmokers. Am J Resp Crit Care Med 1999;159:373-82.

10 Pope CA III, Burnett RT, Thun MJ, et al. Lung cancer, cardiopulmonary mortality, and long-term exposure to fine particulate air pollution. JAMA 2002;287:1132-41.

11 Hoek G, Brunekreef B, Goldbohm S, et al. Association between mortality and indicators of traffic-related air pollution in the Netherlands: a cohort study. Lancet 2002:360:1203-9.

12 Krewski D, Burnett RT, Goldberg MS, et al. Reanalysis of the Harvard six cities study and the American Cancer Society study of particulate air pollution and mortality. Special report. Cambridge, MA: Health Effects Institute, 2000.

13 Schwartz J. Particulate air pollution and daily mortality: a synthesis. Public Health Rev 1991;19:39-60.

14 Sunyer J, Antó JM, Murillo C, et al. Effects of urban air pollution on emergency room admissions for chronic obstructive pulmonary disease. Am J Epidemiol 1991;134:277-86.

15 Pope CAI, Schwartz J, Ransom MR. Daily mortality and PM10 pollution in Utah Valley. Arch Environ Health 1992;47:211-17.

16 Schwartz J, Dockery DW. Increased mortality in Philadelphia associated with daily air pollution concentrations. Am Rev Respir Dis 1992;145:600-4.

17 Dockery DW, Schwartz J, Spengler JD. Air pollution and daily mortality: associations with particulates and acid aerosols. Environ Res 1992;62:362-73

18 Schwartz J. Air pollution and hospital admissions for the elderly in Detroit, Michigan. Am J Resp Crit Care Med 1994;150:648-55.

19 Wordley J, Walters S, Ayres JG. Short term variations in hospital admissions and mortality and particulate air pollution. Occup Environ Med 1997;54:108-16.

20 Schwartz J. Air pollution and daily mortality in Birmingham, Alabama. Am J Epidemiol 1993;137:1136-47.
21 Pope CAI, Kalkstein LS. Synoptic weather modeling and estimates of the exposure-response relationship between daily mortality and particulate air pollution. Environ Health Perspect 1996; 104:414-20.

22 Norris G, YoungPong SN, Koenig JQ, et al. An association between fine particles and asthma emergency department visits for children in Seattle. Environ Health Perspect 1999;107:489-93.

23 Daniels MJ, Dominici F, Samet JM, et al. Estimating particulate mattermortality dose-response curves and threshold levels: an analysis of daily timeseries for the 20 largest US cities. Am J Epidemiol 2000;152:397-406.

24 Schwartz J, Marcus A. Mortality and air pollution in London: a time-series analysis. Am J Epidemiol 1990;131:185-94.

25 Spix C, Heinrich J, Dockery D, et al. Air pollution and daily mortality in Erfurt east Germany, 1980-1989. Environ Health Perspect 1993;101:518-26.

26 World Health Organisation. Guidelines for air quality. Geneva: WHO, 2000 http://www.who.int/peh/air/Airqualitygd.htm (accessed 19 Aug 2003)

27 Alberdi Odriozola JC, Díaz Jiménez J, Montero Rubio JC, et al. Air pollution and mortality in Madrid, Spain: a time-series analysis. Int Arch Occup Environ Health 1998:71:543-9.

28 Rossi G, Vigotti MA, Zanobetti A, et al. Air pollution and cause-specific mortality in Milan, Italy, 1980-1989. Arch Environ Health 1999;54:158-64.

29 Schwartz J, Slater D, Larson TV, et al. Particulate air pollution and hospital emergency room visits for asthma in Seattle. Am Rev Respir Dis 1993;147:826-31

30 Hajat S, Haines A, Goubet SA, et al. Association of air pollution with daily GP consultations for asthma and other lower respiratory conditions in London. Thorax 1999:54:597-605.

31 Tolbert PE, Mulholland JA, Maclntosh DL, et al. Air quality and pediatric emergency room visits for asthma in Atlanta, Georgia, USA. Am J Epidemiol 2000;151:798-810.

32 Schwartz J. Air pollution and hospital admissions for the elderly in Birmingham, Alabama. Am J Epidemiol 1994;139:589-98.

33 Schwartz J, Zanobetti A. Using meta-smoothing to estimate dose-response trends across multiple studies, with application to air pollution and daily death. Epidemiology 2000;11:666-72.

34 World Health Organisation. Health aspects of air pollution with particulate matter, ozone and nitrogen dioxide. Report on a WHO working group, Bonn 13-15 January 2003. Copenhagen: WHO, 2003. http://www.euro.who.int/ document/e79097.pdf (accessed 12 Aug 2003)

35 Atkinson RW, Anderson HR, Strachan DP, et al. Short-term associations between outdoor air pollution and visits to accident and emergency departments in London for respiratory complaints. Eur Respir $J$ 1999:13:257-65

36 Atkinson RW, Bremner SA, Anderson HR, et al. Short-term associations between emergency hospital admissions for respiratory and cardiovascular disease and outdoor air pollution in London. Arch Environ Health 1999:54:398-411.

37 Bremner SA, Anderson HR, Atkinson R, et al. Short term associations between outdoor air pollution and mortality in London 1992-4. Occup Environ Med 1999;56:237-44

38 Atkinson RW, Anderson HR, Sunyer J, et al. Acute effects of particulate air pollution on respiratory admissions: results from APHEA 2 project. Am J Respir Crit Care Med 2001; 164:1860-6. http://ajrccm.atsjournals.org/cgi/ reprint/164/10/1860.pdf (accessed 19 Aug 2003).

39 Katsouyanni K, Touloumi G, Samoli E, et al. Confounding and effect modification in the short-term effects of ambient particles on total mortality: results from 29 European cities within the APHEA2 project. Epidemiology $2001 ; 12: 521-31$

40 Le Tertre A, Medina S, Samoli E, et al. Short-term effects of particulate air pollution on cardiovascular diseases in eight European cities. J Epidemiol Community Health 2002;56:773-9. http://jech.bmijournals.com/cgi/ reprint/56/10/773.pdf (accessed 19 Aug 2003)

41 Zanobetti A, Schwartz J, Samoli E, et al. The temporal pattern of mortality responses to air pollution: a multicity assessment of mortality displacement. Epidemiology 2002;13:87-93.

42 Anderson HR, Atkinson RW, Peacock JL, et al. Publication bias in studies of ambient particulate pollution and daily mortality. Linking exposures and health: innovations and interactions. 12th Conference of the International Society of Exposure Analysis and 14th Conference of the International Society for Environmental Epidemiology. ISEA/ISEE, Vancouver, 2002: no 211.

43 World Health Organisation Regional Office for Europe. Particulate matter. Air quality guidelines for Europe. Copenhagen: WHO, Regional Office for Europe, 2000. http://www.who.dk/document/aiq/7_3particulatematter.pdf (accessed 12 Aug 2003).

44 Department of Health Committee on the Medical Effects of Air Pollutants. Quantification of the effects of air pollution on health in the United Kingdom. London: HMSO, 1998.

45 Mage DT. Public health aspects of air quality surveillance. Public Health Rev 1983;11:5-54

46 Dockery DW, Pope CAI. Acute respiratory effects of particulate air pollution. Ann Rev Public Health 1994;15:107-32.

47 Department of Health Committee on the Medical Effects of Air Pollutants. Non-biological particles and health. London: HMSO, 1995

48 Airborne Particulates Expert Group. Source apportionment of airborne particulate matter in the United Kingdom. London: Department of the Environment, Transport and the Regions, 1999.

49 Task Force on Long Range Transboundary Air Pollution. Health risk of particulate matter from long range transboundary air pollution. Bilthoven: WHO, 1999

50 Künzli N, Kaiser R, Medina S, et al. Health costs due to road trafffic related air pollution-air pollution attributable cases. Bern, Switzerland: Federal 
Department of environment, transport, energy, and communications-Bureau for transport studies, 1999

51 Pope CAl. Particulate matter-mortality exposure-response relations and threshold. Am J Epidemiol 2000;152:407-12.

52 Künzli N, Kaiser R, Medina S, et al. Public-health impact of outdoor and traffic-related air pollution: a European assessment. Lancet 2000;356:795-800.

53 Department of Health Committee on the Medical Effects of Air Pollutants. Statement and report on long-ferm effects of particles on mortality. London: Department of Health, 2001. http://www.doh.gov.uk/comeap/ statementsreports/longtermeffects.pdf (accessed 19 Aug 2003).

54 Department of Health Committee on the Medical Effects of Air Pollutants. Long-term effects of particles on health. COMEAP/2000/17. London: Department of Health, 2000. http://www.doh.gov.uk/comeap/ statementsreports/comeap 17.pdf (accessed 19 Aug 2003).

55 Ostro B, Chestnut L. Assessing the health benefits of reducing particulate matter air pollution in the United States. Environ Res 1998;76:94-106.

56 Joffe M, Mindell J. A framework for the evidence base to support health impact assessment. J Epidemiol Community Health 2002;56:132-8. http:// jech.bmijournals.com/cgi/reprint/56/2/132.pdf (accessed 19 Aug 2003).

$57 \mathrm{Kemm}$ JR. Towards an epidemiology of positive health. Health Prom Int 1993;8:129-34.

58 Samet JM, Dominici F, Zeger SL, et al. The national morbidity, mortality, and air pollution study. Part I: Methods and methodologic issues. 94 part I. Cambridge MA: Health Effects Institute, 2000. http://www.healtheffects.org/ Pubs/Samet.pdf (accessed 19 Aug 2003).

59 Samet JM, Zeger SL, Dominici F, et al. The national morbidity, mortality, and air pollution study. 94 Part II: Morbidity and mortality from air pollution in the United States. Cambridge, MA: Health Effects Institute, 2000. http:// www.healtheffects.org/Pubs/Samet2.pdf (accessed 19 Aug 2003).

60 Dominici F, McDermott A, Zeger SL, et al. On the use of generalized additive models in time-series studies of air pollution and health. Am J Epidemiol 2002; 156:193-203. http://aje.oupjournals.org/cgi/reprint/156/3/ 193.pdf (accessed 19 Aug 2003).

61 Health Effects Institute. Revised analyses of time-series studies of pollution and health. Revised analyses of the national morbidity, mortality, and air pollution Study. Part II. Cambridge, MA: Health Effects Institute, 2002. http:// www.healtheffects.org/Pubs/TimeSeries.pdf (accessed 5 Aug 2003)

62 Ramsay TO, Burnett RT, Krewski D. The effect of concurvity in generalized additive models linking mortality to ambient particulate matter. Epidemiology 2003;14:18-23.

63 Stieb DM, Judek S, Burnett RT. Meta-analysis of time-series studies of air pollution and mortality: update in relation to the use of generalized additive models. J Air Waste Manag Assoc 2003;53:258-61.

64 Samet JM, Dominici F, McDermott A, et al. New problems for an old design: time series analyses of air pollution and health. Epidemiology 2003;14:11-12.

65 Dominici F, McDermott A, Daniels M, et al. Revised results from the national morbidity, mortality, and air pollution study. Cambridge, MA: Health Effects Institute, 2002. http://www.healtheffects.org/Pubs/TimeSeries.pdf (accessed 27 Nov 2003).

66 Stieb DM, Judek S, Burnett RT. Meta-analysis of time-series studies of air pollution and mortality: effects of gases and particles and the influence of cause of death, age, and season. J Air Waste Manag Assoc 2002;52:470-84.

67 Dominici F. Health effects of air pollution: statistical challenges. London: Talk to the Royal Statistical Society, November 2002.

68 Abbey DE, Burchette RJ. Relative power of alternative ambient air pollution metrics for detecting chronic health effects in epidemiological studies. Environmetrics 1996;7:453-70.

69 Hall JV. Assessing health effects of air pollution. Atmos Environ 1996;30:743-6.

70 World Health Organisation. Evaluation and use of epidemiological evidence in environmental health risk assessment. A WHO Guideline document Copenhagen: WHO Regional Office for Europe, 2000.

71 Quality of Urban Air Group. Airborne particulate matter in the UK : third report of the Quality of Urban Air Review Group. Birmingham: Institute of Public and Environmental Health, University of Birmingham, 1996.
72 Neville S. Review and assessment of air quality in the City of Westminster. London: Westminster City Council, 2000.

73 Scaperdas A, Colvile R. Assessing the representativeness of monitoring data from an urban intersection site in Central London, UK. Atmos Environ 2002;22:661-74.

74 Linn WS, Gong HJ, Clark KW, et al. Day-to-day particulate exposures and health changes in Los Angeles area residents with severe lung disease. J Air Waste Manag Assoc 1999;49:108-15.

75 Ostro BD, Chestnut LG. Inappropriate use of daily mortality analyses to estimate longer-term mortality effects of air pollution. Int $J$ Epidemiol 1999;28:990-1.

76 McMichael AJ, Anderson HR, Brunekreef B, et al. Inappropriate use of daily mortality analyses to estimate longer-term mortality effects of air pollution. Int J Epidemiol 1998;27:450-3.

77 McMichael AJ, Anderson HR, Brunekreef B, et al. Inappropriate use of daily mortality analyses to estimate longer-term mortality effects of air pollution. Int J Epidemiol 1999;28:991-2.

78 Dominici F, McDermott A, Zeger SL, et al. Response to Dr Smith: timescaledependent mortality effects of air pollution. Am J Epidemiol 2003;157:1071-3. http://aje.oupjournals.org/cgi/reprint/157/12/ 1071.pdf (accessed 19 aug 2003).

79 Zeger SL, Dominici F, Samet J. Harvesting-resistant estimates of air pollution effects on mortality. Epidemiology 1999;10:171-5.

80 Schwartz J. Harvesting and long term exposure effects in the relation between air pollution and mortality. Am J Epidemiol 2000;151:440-8.

81 Peto R, Lopez AD, Boreham J, et al. Mortality from smoking in developed countries, 1950-2000, indirect estimates from national vital statistics. Oxford: Oxford University Press, 1994

82 Sunyer J, Schwartz J, Tobías A, et al. Patients with chronic obstructive pulmonary disease are at increased risk of death associated with urban particle air pollution: a case-crossover analysis. Am J Epidemiol 2000; 151:50-6.

83 Goldberg MS, Burnett RT, Bailar JC III, et al. Identification of persons with cardiorespiratory conditions who are at risk of dying from the acute effects of ambient air particles. Environ Health Perspect 2001;109(suppl 4):487-94. http://ehpnet1 .niehs.nih.gov/members/2001/suppl-4/487-494goldberg/ EHP109s4p487PDF.pdf (accessed 19 Aug 2003).

84 Pengelly LD, Kerigan AT, Goldsmith CH, et al. The Hamilton study: distribution of factors confounding the relationship between air quality and respiratory health. J Air Pollut Control Assoc 1984;34:1039-43.

85 King K, Stedman J. Analysis of air pollution and social deprivation. A report produced for the Department of the Environment, Transport and the Regions, The Scottish Executive, The National Assembly for Wales and Department of Environment for Northern Ireland. London: ONS, 2000.

86 Hannah J, Morton S, Watkins S. Health on the move: policies for health promoting transport. The policy statement of the Transport and Health Study Group. Birmingham: Public Health Alliance, 1991.

87 British Medical Association. Road transport and health. London: British Medical Association, 1997.

88 Morris JN, Hardman AE. Walking to health. Sports Med 1997;23:306-32. [published erratum appears in Sports Med 1997;24:96]

89 Hillman M. Cycling: towards health and safety. London: British Medical Association, 1992.

90 World Health Organisation. Manual of the international statistical classification of diseases, injuries, and causes of death. London: HMSO, 1977.

91 World Health Organisation. International statistical classification of diseases and related health problems. Geneva, WHO, 1992.

92 World Health Organisation Regional Office for Europe. Air quality guidelines for Europe. 2nd edn. Copenhagen, WHO, Regional Office for Europe, 2000. http://www.euro.who.int/air/Activities/20020620_1 (accessed 19 Aug 2003).

93 Wong CM, Atkinson RW, Anderson HR, et al. A tale of two cities: effects of air pollution on hospital admissions in Hong Kong and London compared. Environ Health Perspect 2002;110:67-77. 


\section{PostScript}

LETTERS

If you have a burning desire to respond to a paper published in the JECH, why not make use of our "rapid response" option?

Log on to our website (www.jech.com) find the paper that interests you, and send your response via email by clicking on the "eletters" option in the box at the top right hand corner

Providing it isn't libellous or obscene, it will be posted within seven days. You can retrieve it by clicking on "read eletters" on our homepage.

The editors will decide as before whether to also publish it in a future paper issue.

\section{No place for modesty}

"A leader is best when people barely know he exists, not so good when people obey and acclaim him, worse when they despise him.. But of a good leader who talks little when his work is done, his aim fulfilled, they will say, "We did it ourselves."

Clearly John Ashton's aphorism mirrors Lao Tzu's thoughts on leadership, and is thus hard to argue against. ${ }^{1}$ However, I think public health practitioners should indeed be "bothered... if we don't get the credit for our own ideas." It is precisely this self effacing stance that has led to the current situation where public health is grossly undervalued and under-resourced. It is hard enough trying to promote a negative-the disease outbreak that didn't happen-we only make it worse for ourselves if we allow others to claim responsibility for all the visible successes.

Why should public health practitioners be employed if the successes are due to the "exertions" of politicians and generic bureaucrats? It is time that we assembled the evidence of our many successes and market public health and its practitioners aggressively. We need to attract the attention of those who procure sickness services at ever increasing expense and show them the folly of neglecting the protectors, promoters, and the preventers. Time to dispense with the bushel and let our lights shine!

C R Douglas

Australasian Faculty of Public Health Medicine PO Box S1296 Perth, WA 6845, Australia charles.douglas@health.wa.gov.au

\section{Reference}

Ashton JR. "Success has 100 parents, failure is an orphan". J Epidemiol Community Health 2003;57:646

\section{Standardised QALYs and DALYs are more understandable, avoid misleading units of measurement, and permit comparisons}

QALYs and DALYs combine years of life and quality of life in a single measure. ${ }^{1-3}$ In Arnesen and Nord's words: "DALYs and QALYs are complementary concepts. QALYs are years of healthy life lived; DALYs are years of healthy life lost. Both approaches multiply the number of years ( $\mathrm{x}$ axis) by the quality of those years (y axis). QALYs use "utility weights" of health states; DALYs use "disability weights" to reflect the burden of the same states. For example, if the utility of deafness is 0.67 , the disability weight of deafness is $1-0.67=0.33$. Disregarding age weighting and discounting, and assuming lifetime expectancy of 80 years, a deaf man living 50 years represents $0.67 \times 50=33.5$ QALYs gained and $0.33 \times 50+1.0 \times(80-50)$ $=46.5$ DALYs lost". ${ }^{\prime 2}$ We can see that $33.5+46.5=80.0$ - that is, QALYs+DALYs = lifetime expectancy.

If we would like to be more accurate, we had to put QALYs $=0.67 \times 50 y=33.5 y$ and DALYs $=0.33 \times 50 y+1.0 \times(80 y-30 y)=46.5 y$. This means that the unit of measurement of QALYs and DALYs is years (y). As y is the unit of measurement of lifetime, using the same unit for the product "lifetime $\times$ lifequality" is confusing

Saying that quality is rated on a scale from 0 to 1 , we, in fact, have implicitly transformed the real but unknown scale of quality into a standard scale, where 0 denotes no quality at all and 1 the $100 \%$ of quality expected (lifequality expectancy). Therefore, QALYs and DALYs, combining actual years (axis $\mathrm{x}$ ) and dimensionless quality (axis y), are, in fact, semi-standardised measures.

We can do the same with the dimension of time, assigning 0 to birth and 1 to lifetime expectancy. Continuing the example above, the dimensionless $\mathrm{l}$ is assigned to $80 \mathrm{y}$, the dimensionless 0.625 to $50 \mathrm{y}(50 \mathrm{y} / 80 \mathrm{y})$ and the dimensionless 0.375 to $30 \mathrm{y}(30 \mathrm{y} / 80 \mathrm{y})$. Thus, fully standardised QALYs $=$ SQALYs $=0.67 \times$ $0.625=0.41875$, and fully standardised DALYs $=$ SDALYs $=0.33 \times 0.625+1.00 \times 0.375$ $=0.58125$; that is, $41.875 \%$ of the life expected to be lived was actually lived and $58.125 \%$ was lost. Again SQALYs+SDALYs = $1=100 \%=$ life expectancy

These transformed to fully dimensionless standardised measures seem to be more understandable: SQALYs are the percentage of life lived, and SDALYs the percentage of life lost; as their sum equals 1, they are complementary. They do not measure life as lifetime; therefore they are not misleading. And thirdly they permit comparisons between countries, nations, sub-nations, etc, with different lifetime expectancy.

In contrast, we could of course unstandardise both axes, by assigning lifequality its real scale, but it remains to be discovered.

Department of Hygiene and Epidemiology, Medical School, University of loannina, 45110 loannina, Greece; idimolia@cc.uoi.gr

doi: 10.1136/jech.2003.014167

\section{References}

1 Murray CJL, Lopez AD. Global burden of disease study, Lancet 1997:349:1269-76, 1347-52, 1436-42, 1498-504.

2 Arnesen T, Nord E. The value of DALY life: problems with ethics and validity of disability adjusted life years. BMJ 1999;319:1423-5.
3 Gold MR, Stevenson D, Fryback DG. HALYs and QALYs and DALYs, oh my: similarities and differences in summary measures of population health. Annu Rev Public Health 2002;23: 115-34

\section{Previous trials of dissemination were identified}

Morrison et al examine the effect on ques tionnaire response of feeding back research findings to participants. ${ }^{1}$ As authors of the systematic review ${ }^{2}$ cited in their paper we would like to point out that we had in fact identified eight such randomised trials. ${ }^{3-10}$ The broad strategy under which these trials had been classified in our review was "nonmonetary incentives". We are currently updating our systematic review and have recently extended the search of databases to the beginning of 2003 and have contacted the authors of potentially eligible trials. A further two trials ${ }^{11} 12$ have been identified and the total of 10 trials have also been classified under the new strategy called "offer of research findings". These trials include a total of 13642 participants. When the results of these trials are pooled in a random effects meta analysis the odds ratio for response with research findings is 0.92 (95\% CI 0.75 to 1.11). Despite omitting to refer to these previous trials, Morrison et al were justified in conducting their trial: few of such trials have been health related and none has examined the effect of this intervention when participants are being resurveyed. However, even with the inclusion of their new trial in our systematic review, uncertainty about the effect of dissemination of research findings on questionnaire response remains.

The update to our systematic review now includes a total of 372 trials of methods to influence response to postal questionnaires, classified under 98 strategies. Although many conclusions remain unchanged our updated review presents the definitive account of the evidence for which strategies may be used to improve response to postal questionnaires. The updated review will appear in the Cochrane Library later this year.

P Edwards, R Cooper Department of Epidemiology and Population Health London Schoo of Hygiene and Tropical Medicine London, UK

Correspondence to: Mr P Edwards, LSHTM, 49-51 Bedford Square, London WC1B3DP, UK phil.edwards@|shtm.ac.uk

\section{References}

1 Morrison DS, Thomson H, Petticrew M. Effects of disseminating research findings on response rates in a community survey: a randomised controlled trial. J Epidemiol Community Health 2003;57:536-7

2 Edwards $\mathbf{P}$, Roberts I, Clarke $M$, et al. Increasing response rates to postal questionnaires: systematic review. BMJ 2002:324:1183-5.

3 Dommeyer CJ. Does response to an offer of mail survey results interact with questionnaire interest? Journal of the Market Research Society 1985; 27:27-38.

4 Dommeyer CJ. Offering mail survey results in a lift letter. Journal of the Market Research Society 1989:31:399-408

5 Glisan G, Grimm JL. Improving response rate in an industrial setting: will traditional variables 
work? Southern Marketing Association Proc 1982;20:265-8.

6 Green KE, Kvidahl RF. Personalization and offers of results: effects on response rates. Journal of Experimental Education 1989;57:263-70.

7 Jobber D, Sanderson S. The effect of two variables on industrial mail survey returns. Industrial Marketing Management 1985; 14:119-21.

8 Kerin RA, Barry TE, Dubinsky AJ, et al. Offer of results and mail survey response from a commercial population: a test of Gouldner's norm of reciprocity. Proceeding of the American Institute of Decision Sciences 1981:283-5.

9 Mullner RM, Levy PS, Byre CS, et al. Effects of characteristics of the survey instrument on response rates to a mail survey of community hospitals. Public Health Rep 1982;97:465-9.

10 Powers DE, Alderman DL. Feedback as an incentive for responding to a mail questionnaire. Research in Higher Education 1982;17: 207-11.

11 Thistlethwaite PC. The impact of selected mail response enhancement techniques on surveys of the mature market: some new evidence. Journal of Professional Services Marketing 1993:8:269-76.

12 Wiseman F. Methodological bias in public opinion surveys. Public Opinion Quarterly 1972;36:105-8.

\section{BOOK REVIEWS}

\section{Terrorism and public health: a balanced approach to strengthening systems and protecting the public}

Barry S Levy, Victor W Sidel, editors. (Pp 377; £35.00). Oxford University Press, New York 2003. ISBN 0-19-515834-2

The preface states: "we believe this is the firs book that addresses terrorism from a public health perspective that is both comprehensive and balanced" (page xi). To a large extent, the book fulfils this promise, offering an informative, up to date, and highly readable summary of a broad range of public health issues that interface with the problem of international terrorism.

Part I has an introductory chapter followed by seven chapters examining public health challenges emerging after the September 11 th attacks. Four of these chapters summarise events in New York City, one covers the anthrax epidemic, one covers public health problems in war strapped Afghanistan, and one chapter offers an erudite and much needed account of the prospects for educating, informing, and mobilising the public.
Much of the material in part I is based on firsthand experience, and it is packed with information and insights that are unlikely to be found elsewhere. Part II covers conventional, biological, chemical, nuclear, and radiological terrorist weapons. Attention often focuses on arms control and its political underpinnings, but clinical aspects are also covered (though in too little detail to provide an important reference for clinicians). Part III addresses terrorism related "challenges and opportunities," with chapters aimed at public health systems, epidemiology, therapeutic interventions, research, environmental protection, civil liberties, roots of terrorism, and the promotion of international law. The comprehensiveness of the text suffers slightly from the lack of attention to methods of decontamination, structure and function of Incident Command Systems, and the coordination of disaster services under the Federal Emergency Management Agency.

The text is well "balanced" in the manner intended by the authors in so far as it nicely situates the need for terrorism prevention and response capabilities within the context of other, potentially competing public health needs, and it balances these needs against the imperative to avoid "inappropriate or hazardous responses to threats of future terrorism." On the other hand, there is little balance between competing viewpoints on ethical or policy issues. The book is structured by liberal cosmopolitan ideology-including numerous attacks on the Bush administration-with no attempt to fairly represent the range of credible, diverging opinions about the nature of justice or the intricacies of international collaboration and arms control.

G Trotter

\section{Dawning answers: how the HIV/ AIDS epidemic has helped to strengthen public health}

Ronald O Valdiserri, editor. (Pp 209; £29.92). Oxford University Press, 2003. ISBN 0-19514740-5

The HIV epidemic is still a great threat to public health, and the complexity of the infection regarding both biological and social aspects has challenged our skills to prevent its spread. The book presents a historica analysis to inform current policy development and to forecast the future, and describes some very important lessons learned during more than two decades with the HIV epidemic.
HIV has influenced the development and understanding of the use of multiple surveillance methods, integrated case based and behavioural surveillance, active collaboration between different public health stakeholders, and confidentiality and anonymity have become important issues.

Although sex may well be the most pleasurable human activity it is also very tabooed. The HIV risk reduction thus entails difficult behaviour changes, and the involvement of community members in this public health activity has become crucial. The adoption of "grey area" behaviours among at risk populations has led to the need for structural and individual level intervention. The HIV epidemic has shown the necessity of understanding surveillance data in their social context, for example, sex for drug. At the same time the "All or nothing" thinking opened to the principle of harm reduction.

The HIV epidemic has shown the importance of translating research results into active intervention and routine service delivery. HIV has had an impact on the organisation of prevention and care services and the public health planners are urged to consider the entire healthcare system, using all data available. Legal aspects and ethical issues, such as human rights, especially in relation to testing policy, named reporting and partner notification are very well discussed in the book.

The nine chapters are mainly dealing with the situation in the USA, however, the history in most western countries is similar and the book is absolutely worth reading for those interested in public health and in the HIV/ AIDS epidemic and policy. The public health challenges from infection diseases never stop.

E Smith

\section{CORRECTIONS}

doi: 10.1136/jech.2003.010553corr

An editorial error occurred in this paper by Dr Malinauskiene and others (2004;58:1315). The affiliation of $\mathrm{Dr} \mathrm{R}$ Malinauskas is Department of Psychology, Lithuanian Academy of Physical Education (this was omitted from the article).

doi: 10.1136/jech.2003.009589corr

An editorial error occurred in this paper by Drs Mindell and Joffe $(2004 ; 58: 103-13)$. In table 3, the age group for the first row of IHD admissions should be 0-64 (not 0-4). 